\title{
CLINICAL AND IMMUNOLOGICAL FEATURES OF ROTAVIRUS GASTROENTERITIS IN CHILDREN INFECTED WITH HERPES VIRUSES
}

\author{
${ }^{I}$ Professor Sergiy Kuznecov, \\ ${ }^{2}$ Marharyta Sliepchenko
}

\author{
Ukraine, Kharkiv, Kharkiv National Medical University; \\ ${ }^{1}$ Head of the Department of Pediatric Infectious Diseases; \\ ${ }^{2}$ Assistant of the Department of Pediatric Infectious Diseases
}

DOI: https://doi.org/10.31435/rsglobal_ws/30122019/6826

\section{ARTICLE INFO}

Received: 16 October 2019

Accepted: 12 December 2019

Published: 30 December 2019

\section{KEYWORDS}

children,

rotavirus infection,

herpes viruses,

clinical manifestations,

cellular link of the immune response.

\begin{abstract}
The article presents the results of a comparative analysis of clinical and immunological parameters in children with rotavirus gastroenteritis without background infection and those infected by herpes viruses. It was established that in children with rotavirus infection (RVI) on the background of infection by herpes viruses occurs with less pronounced symptoms of intoxication and a less frequency of vomiting at the onset of the disease, in combination with longer duration (more long period) of fever and diarrheal syndrome. Such features are probably associated with the formation of a hypergical regime of the functioning of the immune response in the group of patients with background infection by herpes viruses, in contrast to patients with mono$\mathrm{RVI}$, in whom the immune system functions in a normal compensation mode.
\end{abstract}

Citation: Sergiy Kuznecov, Marharyta Sliepchenko. (2019) Clinical and Immunological Features of Rotavirus Gastroenteritis in Children Infected with Herpes Viruses. World Science. 12(52), Vol.1. doi: 10.31435/rsglobal_ws/30122019/6826

Copyright: (C) 2019 Sergiy Kuznecov, Marharyta Sliepchenko. This is an open-access article distributed under the terms of the Creative Commons Attribution License (CC BY). The use, distribution or reproduction in other forums is permitted, provided the original author(s) or licensor are credited and that the original publication in this journal is cited, in accordance with accepted academic practice. No use, distribution or reproduction is permitted which does not comply with these terms.

Introduction. Rotavirus infection (RVI) is the most common cause of diarrhea in childhood [1, 2]. According to WHO experts, almost every child during the first three to five years of life suffers from specified infection, despite on of nationality, race and socio-economic status of the family $[8,14]$. The high frequency of development of severe forms of rotavirus gastroenteritis in young children, the difficulties in treating patients, and the negative consequences of the disease (imbalance of the gut microbiota, decreased immune forces of the body, etc.) determine the relevance of this pathology $[4,15]$. In recent years, the interest of scientists has been attracted by the problem of immunopathogenesis of intestinal infections, including rotavirus etiology, various exogenous and endogenous factors that can change the immune response of patients and, as a result, the clinical manifestations of the disease and its course [3, 6, 7]. According to a number of authors, one of these factors is the viruses of the herpes group, which are widespread in the human population, with which a significant portion of children are currently infected $[5,9]$.

However, there are very few works that would consider the clinical features of the clinical course of rotavirus gastroenteritis in children infected by herpes viruses in the available literature, and their results are very contradictory $[2,4,12]$. Meanwhile, their identification, in our opinion, will contribute to the development of affordable, clinically justified, informative methods for diagnosing the presence of herpes virus infection in children with intestinal infections of rotavirus etiology. In addition, the results of studies to identify the peculiarities of the immune mechanisms of the development of the disease in children infected with herpes viruses will help to clarify the pathogenetic links in the formation of the pathological process, which later may be the basis for improving the treatment of patients. 
Purpose: to identify the characteristics of the clinical course of diseases of the gastrointestinal tract of rotavirus etiology and the immune response of patients infected with herpes viruses.

\section{Subjects \& Methods.}

Under the supervision were 64 children aged one to three years, patients with moderate and severe forms of intestinal infection of rotaviral etiology, about which they received appropriate treatment in the regional children's infectious diseases clinical hospital in Kharkov. Of these, 31 (the first group) did not have background infection and 33 (the second group) underwent RVI against the background of infection by herpes viruses. Children of these groups were comparable by sex, age, disease severity and other parameters.

Verification of the diagnosis of RVI was carried out using the allocation rotavirus antigen from feces of patients by enzyme-linked immunosorbent assay (ELISA) and the corresponding antibodies of the IgM class in the blood. The presence of herpesvirus infection was proved on the basis of the detection of IgG antibodies to herpes viruses of types $1,2,4,5,6$ in the blood of children. The study did not include patients with the presence in their blood serum of antibodies of the IgM class (ELISA) and nucleic acid (PCR) of 1,2,4,5,6 types of herpes viruses. All children were also examined for the presence of other viral and / or bacterial pathogens of intestinal infections (feces), with a positive result, such patients were excluded from the examination cohort. Along with generally accepted clinical and laboratory examinations in the blood of the observed children in the dynamics of the disease (1-2 days and 8-10 days), the levels of $\mathrm{CD} 3+$ (T-lymphocytes), CD4 + (T-helpers), CD8 + (T-suppressors), CD16 + (NK-cells), CD22 + (Blymphocytes) cells by immunofluorescence using monoclonal antibodies.

Statistical processing of the results was carried out taking into account the arithmetic mean and standard error of the arithmetic mean. The reliability of the difference (p) of the two samples was evaluated by using Student's criterion ( $\mathrm{t}$ ). The calculations were carried out on a personal computer using Microsoft Excel programme.

All research methods were conducted in compliance with human rights, respectively, the current legislation of Ukraine and international ethical requirements. As a control, we used the results of relevant examinations of healthy children received by the applicant of the department E.S. Olkhovsky (2018) [16].

\section{Conflict of interests.}

There is no conflict of interests.

\section{Research results and discussion.}

An analysis of clinical data revealed that in children of both groups the disease began mainly acutely with an increase in body temperature, the appearance of vomiting and frequent loose stools (Table 1).

Table 1. The frequency of identification of the main clinical symptoms and their duration in children of the compared groups

\begin{tabular}{|l|l|l|l|}
\hline Clinical symptoms & \multicolumn{1}{|c|}{$\begin{array}{c}\text { I group }(\mathrm{n}=31) \\
\mathrm{M} \pm \mathrm{m}\end{array}$} & \multicolumn{1}{|c|}{$\begin{array}{r}\text { II group }(\mathrm{n}=33) \\
\mathrm{M} \pm \mathrm{m}\end{array}$} & $\mathrm{p}$ \\
\hline $\begin{array}{l}\text { Level of temperature } \\
\text { reaction }\left({ }^{\circ} \mathrm{C}\right)\end{array}$ & $39,17 \pm 0,21$ & $38,42 \pm 0,18$ & $\mathrm{p}<0,05$ \\
\hline $\begin{array}{l}\text { Catarrhal syndrome } \\
\text { occurrence in patients) }\end{array}$ & $28,05 \pm 0,21$ & $27,92 \pm 0,16$ & $\mathrm{p}>0,05$ \\
\hline $\begin{array}{l}\text { The frequency of } \\
\text { vomiting (day) }\end{array}$ & $6,12 \pm 0,29$ & $4,08 \pm 0,37$ & $\mathrm{p}<0,05$ \\
\hline $\begin{array}{l}\text { The frequency of } \\
\text { defecation (day) }\end{array}$ & $7,86 \pm 0,25$ & $8,05 \pm 0,14$ & $\mathrm{p}>0,05$ \\
\hline Duration of fever (days) & $2,58 \pm 0,33$ & $4,02 \pm 0,24$ & $\mathrm{p}<0,05$ \\
\hline $\begin{array}{l}\text { Duration of vomiting } \\
\text { (days) }\end{array}$ & $2,52 \pm 0,08$ & $2,35 \pm 0,05$ & $\mathrm{p}>0,05$ \\
\hline $\begin{array}{l}\text { Duration of diarrhea } \\
\text { syndrome (days) }\end{array}$ & $4,36 \pm 0,25$ & $6,12 \pm 0,82$ & $\mathrm{p}<0,05$ \\
\hline
\end{tabular}

The increase in body temperature in children of group I ranged on average within $39.17 \pm$ $0.21^{\circ} \mathrm{C}$, while in patients of group II $-38,42 \pm 0.18^{\circ} \mathrm{C}(\mathrm{p}<0.05)$. Catarrhal manifestations in the form 
of hyperemia of the mucous membrane of the oropharynx and serous discharge from the nose were observed almost equally often in the compared groups, which does not contradict the results of clinical observations O. Usachova (2013) [18]. Vomiting in children not infected by herpes viruses in the onset of the disease was recorded from one to eight to nine times a day $6.12 \pm 0.29$, while in children with background infection more often was observed one to five times a day $4.08 \pm 0.37(p<0.05)$.

The frequency of stool was almost the same in children of the compared groups ( $p>0.05)$, although the nature of feces in some patients, infected by herpes viruses, was enterocolitic, which, according to some authors, may be associated with a decrease in their immunity response to the action of herpes viruses and, as a result, the involvement of a larger segment of the intestinal tube in the process [17].

A comparative analysis of clinical observations found that in children not infected with Herpes viruses, the RVI debut is characterized by a more pronounced temperature reaction of patients, a more significant frequency of vomiting, with almost the same severity of catarrhal phenomena and diarrheal syndrome. When observing children in the dynamics of the disease, differences in the timing of the relief of the clinical manifestations of the disease in the compared groups were revealed. (Table 1). We found that in children infected by herpes viruses, increased body temperature $(p<0.05)$ and dysfunction persisted for a longer time intestines $(\mathrm{p}<0.05)$, with almost the same duration of catarrhal phenomena and vomiting in comparison with sick uninfected herpes viruses. Given the differences in the severity of clinical manifestations of RVI at the beginning of the disease and their duration in dynamics, we investigated the level of subpopulations of $\mathrm{T}$ and $\mathrm{B}$ lymphocytes in children of the compared groups during the course of the disease (Table 2).

Table 2. Indicators of cellular immunity in children of comparable groups at different periods of the disease

\begin{tabular}{|c|c|c|c|c|c|}
\hline \multirow[t]{2}{*}{ Indicators } & \multicolumn{2}{|c|}{ I group $(n=31) M \pm m$} & \multicolumn{2}{|c|}{ II group $(n=33) M \pm m$} & \multirow{2}{*}{\begin{tabular}{|l}
$\begin{array}{l}\text { Healthy } \\
\text { children }\end{array}$ \\
$(\mathrm{M} \pm \mathrm{m})$ \\
$(\mathrm{n}=30)$
\end{tabular}} \\
\hline & $\begin{array}{l}\text { Acute } \\
\text { period }\end{array}$ & $\begin{array}{l}\text { Period of } \\
\text { convalescence }\end{array}$ & $\begin{array}{l}\text { Acute } \\
\text { period }\end{array}$ & $\begin{array}{l}\text { Period of } \\
\text { convalescence }\end{array}$ & \\
\hline $\mathrm{CD} 3+\%$ & $57,66 \pm 1,23$ & $59,04 \pm 0,88^{*}$ & $51,23 \pm 1,94$ & $55,18 \pm 0,76^{* \mathrm{o}}$ & $60,60 \pm 1,20$ \\
\hline $\mathrm{CD} 4+, \%$ & $30,35 \pm 0,43$ & $35,66 \pm 0,92$ & $30,09 \pm 0,32$ & $32,01 \pm 1,43^{* 0}$ & $36,30 \pm 0,75$ \\
\hline $\mathrm{CD} 8+, \%$ & $22,04 \pm 1,61$ & $24,94 \pm 1,32$ & $29,09 \pm 0,34 * 0$ & $26,36 \pm 2,37$ & $25,97 \pm 1,68$ \\
\hline CD4+/CD8+ & $1,71 \pm 0,51$ & $1,68 \pm 1,65$ & $1,08 \pm 0,62$ & $1,64 \pm 0,65$ & $1,52 \pm 0,87$ \\
\hline $\mathrm{CD} 16+, \%$ & $16,09 \pm 1,05$ & $19,63 \pm 1,62$ & $15,76 \pm 0,65$ & $16,75 \pm 1,20$ & $17,30 \pm 0,79$ \\
\hline $\mathrm{CD} 22+, \%$ & $19,43 \pm 0,87$ & $28,31 \pm 0,46^{\circ *}$ & $20,87 \pm 0,14$ & $24,92 \pm 0,73$ & $21,03 \pm 1,27$ \\
\hline
\end{tabular}

Note. ${ }^{\circ}$ - reliability of the difference in the performance of children of groups I and II in comparison with healthy ones. * - the reliability of the difference in indicators in the comparison of children of groups I and II.

In the acute period of the disease in children with rotavirus mono-infection, the levels of $\mathrm{CD} 3+, \mathrm{CD} 4+, \mathrm{CD} 8+$ did not significantly differ from the corresponding indices of the control group. Moreover, in children infected with herpes viruses, the relative content of CD3 +, CD4 + subpopulations of T-lymphocytes was slightly reduced ( $p>0.05$ ) with a significantly increased level of CD8 + T-lymphocytes relative to healthy children and with mono-RVI ( $<<0.05$ ), which coincides with the data of other authors $[10,11]$.

In the acute period of the disease, the immunoregulatory index (CD4 + / CD8 +) was increased in children without background infection relative to the control, in patients with rotavirus gastroenteritis proceeding against infection with herpes viruses, A I was slightly lower than in the comparison groups, which is probably due to a more significant increase in their blood levels of CD8 + T-lymphocytes ( $\mathrm{p}>0.05)$. 
The relative content of a subpopulation of T-lymphocytes expressing $\mathrm{C} 16+$ on their membrane was higher in patients with rotavirus mono-infection $(\mathrm{p}>0.05)$.

The low level of CD16 + T-lymphocytes in children with latent herpesvirus infection is probably associated with the active participation of these cells in the elimination of damaged, including herpesvirus, host cells. With mixed infections, the energy balance of cells decreases, hence the more rapid onset of apoptosis. [9]

By the convalescence period, the level of CD3 + and CD4 + T-lymphocytes in children of both groups increased, however, in patients with background infection it was less significant and did not reach the level of the control group ( $p<0.05)$, in contrast to children with mono-RVI $(p>0.05)$. The level of CD8 + cells on the 8-10-th day of illness in children of the first group increased, while in children of the second group it decreased.

The levels of B-lymphocytes (CD 22+) in children with combined rotavirus infection in the acute period of the disease did not exceed the corresponding indicators for children with mono-RVI and amounted to $19.43 \pm 0.87$ and $20.87 \pm 0.14$ ( $>>0,05$ ), respectively. During the convalescence period, there was a significant increase in the level of CD22 + lymphocytes in children with monoRVI $(28.31 \pm 0.46)$ compared with patients with background infection $24.92 \pm 0.73(\mathrm{p}<0.05)$ and healthy children $21.03 \pm 1.27(\mathrm{p}<0.05)$.

When studying immunological parameters, it was revealed that in patients with mono-RVI during the disease, the immunity T-system functions in the normal compensation mode, as evidenced by the absence of significant changes in the parameters relative to the control group. While in children with combined rotavirus and herpesvirus infection it is hyperegic, which was confirmed by: a decrease in the relative number of subpopulations of $\mathrm{CD} 3+, \mathrm{CD} 4+$ and $\mathrm{CD} 16+\mathrm{T}$-lymphocytes against the background of an increase in CD $8+$ cells with a subsequent delay in normalization and decreased CD $22+$ in the period of convalescence.

Conclusions. The results of the study indicate that the clinical features of RVI in children infected by herpes viruses are characterized by less pronounced symptoms of intoxication, which is indicated by lower level of the temperature reaction of patients and a more rare of vomiting, with almost the same frequency of bowel movements and the severity of catarrhal syndrome at the onset of the disease.

Moreover, the duration of clinical symptoms of the disease in children with herpes viruses infection was longer in comparing with group 1.

In our opinion, these features are explained due to the formation of various modes of functioning of the immune response of children. In patients with mono-RVI, the immune system functions in the normal compensation mode, and in children with the presence of background infection by herpes viruses in the hypergical mode. The revealed clinical and immunological differences can be the basis for creating diagnostic algorithms for the presence of herpesvirus infection in children with rotavirus gatsroenteritis, and at the same time an argument in favor of revising the scope of therapeutic intervention.

\section{REFERENCES}

1. S.G. Gorbunov, L.N. Mazankova, I.D. Maykova, O.I. Demina, E.P. Koval. Features of the immune response and the efficacy of immunotherapy for Rotavirus infection in children. Detskie Infektsii=Children's Infections. 2018; 17 (3):38-46. doi.org/10.22627/2072-8107-2018-17-3-38-46

2. Майданник, В.Г. Особенности клеточного звена иммунитета у детей, больных моно- и микствариантами ротавирусной инфекции / В.Г. Майданник, К.О. Смеян-Горбунова // Здоровье ребенка. 2015. - №2 (61). - C. 15-18.

3. Mokomane, M., Kasvosve, I., de Melo, E., Pernica, J. M., \& Goldfarb, D. M. (2018). The global problem of childhood diarrhoeal diseases: emerging strategies in prevention and management. Therapeutic advances in infectious disease, 5(1), 29-43. doi:10.1177/20499361177444429

4. Бабик Р.К. Клинико-иммунологические особенности ротавирусной инфекции у детей / Р.К. Бабик, Е.В. Корнеева // Вестник Южно-Уральского государственного университета. Серия «Образование, здравоохранение, физическая культура». - 2011. — № 28. - С. 53-57.

5. Зайцева, Л.Ю. Клинико-иммунологические особенности течения вирусных диарей у детей / Л.Ю. Зайцева, И.Г. Хмелевская, П.В. Калуцкий // Вестник современной клинической медицины. - 2017. - №2. - С. 30-33.

6. Holloway G. Innate cellular responses to rotavirus infection / G. Holloway, B.S. Coulson // J. Gen. Virol. - 2013. - Vol. 94(6). - P. 1151-1160.

7. Herpesvirus Evasion of Natural Killer CellsSteffi De Pelsmaeker, Nicolas Romero, Massimo Vitale, Herman W. Favoreel Journal of Virology May 2018, 92 (11) e02105-17; doi: 10.1128/JVI.02105

8. Estimates of the global, regional, and national morbidity, mortality, and etiologies of diarrhea in 195 countries: a systematic analysis for the Global Burden of Disease Study 2016/ The Lancet Infectious Diseases//September 19, 2018 
9. Дюдюн А. Д. Герпесвирусная инфекция. Клинико-иммунологические особенности. Клиническая лекция/ Дюдюн А. Д Полион Н. Н., Нагорный А. Е.// Дерматовенерология. Косметология. Сексопатология, 3-4 , 2015, С.: 119-142.

10. Immune Protection against Virus Challenge in Aging Mice Is Not Affected by Latent Herpesviral Infections/Marandu $\mathrm{TF}^{1}$, Oduro $\mathrm{JD}^{2}$, Borkner $\mathrm{L}^{2}$, Dekhtiarenko $\mathrm{I}^{2}$, Uhrlaub $\mathrm{JL}^{3}$ //J Virol. 2015 Nov;89(22):11715-7. doi: 10.1128/JVI.01989-15. Epub 2015 Sep 2.

11. White DW, Suzanne Beard R, Barton ES. Immune modulation during latent herpesvirus infection. Immunol Rev. 2012;245(1):189-208. doi:10.1111/j.1600-065X.2011.01074.x

12. К. О. Сміян-Горбунова, Т. П. Бинда, О. І. Сміян. Стан гуморальної ланки імунної системи в дітей 3 моно- та мікст-варіантами ротавірусної інфекції/ Scientific Journal «ScienceRise» №9/3(14)2015 doi: $10.15587 / 2313-8416.2015 .50227$

13. Иммунологические особенности вирусных кишечных инфекций у детей. Ермоленко К.Д., КуляшоваЛ.Б., Рощина Н.Г., Ермоленко Д.К., Раздьяконова И.В., Гончар Н.В. Фарматека 11 (344) 2017; c. 67-71.

14. Оценка прямого экономического ущерба, наносимого ротавирусной инфекцией. Михеева И.В. Михеева М.А. Инфекционные болезни 2017.-N 4.-C.95-99.

15. Shin M., Salamanca B.V., Kristiansen I.S., Flem E. Healthcare Costs of Rotavirus and Other Types of Gastroenteritis in Children in Norway. Pediatr. Inf. Dis. J. 2016;35(4):97-101.

16. Є. С. Ольховський. Особливості клінічного перебігу ешерихіозу у дітей, інфікованих вірусом ЕпштейнаБарр. С. С. Ольховський, С. В. Кузнєцов/ Експерементальная і клінічна медицина // 2016. 4 (73). С.: 73-77.

17. ZaytsevaLYu, Khmelevskaya IG, Kalutskiy PV (2017). Clinical and immunological features of viral diarrhea in children. The Bulletin of Contemporary Clinical Medicine. 10 (2): 30-33.

18. Усачова, О. В., Пахольчук, Т. М., Сіліна, Є. А., Матвеєва, Т. Б., Шульга, О. В., Печугина, В. В., ... \&Турлюн, В. А. (2013). Особливості перебігу ротавірусної інфекції у дітей раннього віку 3 цитомегалією та підходи до патогенетичної терапії. Современная педиатрия, (1), 134-138. 